Al Maal : Journal of Islamic Economics and Banking

http://jurnal.umt.ac.id/index.php/jieb

E-ISSN : $2580-3816$

Vol : 2 No. 2 Bulan Januari Tahun 2021

Hlm : $160-177$

DOI : 10.31000/almaal.v2i2.3111

\title{
Pengaruh Pembiayaan Murabahah, Pembiayaan Mudharabah dan Pembiayaan Musyarakah Terhadap Profitabilitas
}

\author{
Citra Intan Purnama Sari ${ }^{1, *}$, Sulaeman ${ }^{2}$ \\ 1,2,3Prodi Akuntansi, Fakultas Ekonomi Universitas Muhammadiyah Sukabumi, Indonesia \\ *citraintanpurnama.s@gmail.com
}

\begin{abstract}
This study aims to determine the effect of murabahah financing, mudharabah financing and musyarakah financing on the level of profitability. This research was conducted using quantitative methods with an associative approach. The object of this research is the three Sharia Commercial Bank financial statements for the period 2016-2019 as many as three Islamic Commercial Banks and a sample of 48 financial reports. In this study, sampling was using purposive sampling technique. Data collection techniques using secondary data. The data analysis technique used is the classical assumption test, multiple linear analysis, and hypothesis testing. The results of this study indicate that murabahah financing has a positive effect on ROA with a significant level of 0.000. Mudharabah financing has a positive effect on ROA with a significant level of 0.000. Meanwhile, musyarakah financing has no positive effect on ROA with a significance level of 0.000. Meanwhile, simultaneously Murabahah Financing, Mudharabah Financing and Musharaka Financing have an effect of $91 \%$ on the level of Profitability at Islamic Commercial Banks in Indonesia for the period 2016-2019, the remaining 9\% is influenced by other factors not examined by the authors in this study.
\end{abstract}

Keywords: Murabahah Financing; Mudharabah Financing; Musyarakah Financing; ROA.

\begin{abstract}
ABSTRAK
Penelitian ini bertujuan untuk mengetahui pengaruh pembiayaan murabahah, pembiayaan mudharabah dan pembiayaan musyarakah terhadap tingkat profitabilitas. Penelitian ini dilakukan dengan menggunakan metode kuantitatif dengan pendekatan asosiatif. Objek dalam penelitian ini adalah laporan keuangan Bank Umum Syariah pertriwulan periode 2016-2019 sebanyak Tiga Bank Umum Syariah dan diambil sampel 48 laporan keuangan. Dalam penelitian ini pengambilan sempel dengan teknik purposive sampling. Teknik pengumpulan datanya dengan menggunakan data skunder. Teknik analisis data yang digunakan adalah uji asumsi klasik, analisis linear berganda, dan uji hipotesis. Hasil penelitian ini menunjukan bahwa pembiayaan murabahah berpengaruh positif terhadap ROA dengan tingkat signifikan 0,000. Pembiayaan mudharabah berpengaruh positif terhadap ROA dengan tingkat signifikan 0,000. Sedangkan untuk pembiayaan musyarakah tidak berpengaruh positif terhadap ROA dengan tingkat signifikansi 0,000. Sedangkan secara simultan Pembiayaan murabahah, pembiayaan Mudharabah dan Pembiayaan Musyarakah berpengaruh sebesar 91\% terhadap tingkat Profitabilitas pada Bank Umum Syariah di Indonesia periode 2016-2019, yang sisanya 9\% dipengaruhi oleh faktor-faktor lainnya yang tidak diteliti oleh penulis dalam penelitian ini.
\end{abstract}

Kata kunci: Pembiayaan Murabahah; Pembiayaan Mudharabah; Pembiayaan Musyarakah; ROA. 


\section{Pendahuluan}

Perbankan di Indonesia kini berada dalam masa kejayaannya dan mengalami perkembangan yang pesat. Bank terbagi menjadi dua jenis ditinjau dari segi prinsipnya yaitu Bank konvensional dan Bank Syariah. Kedua jenis bank ini memiliki produk bank yang hampir sama, hanya saja berbeda pada system operasinya. Menurut Ismail, (2011) "Bank syariah adalah bank yang dalam sistem operasionalnya tidak menggunakan sistem bunga, akan teteapi menggunakan prinsip dasar sesuai dengan syariah islam."

Tujuan akhir bank syariah sama sebagaimana halnya perusahaan yaitu untuk menjamin kelangsungan hidup dengan upaya untuk memperoleh keuntungan. Kinerja bank menjadi tolak ukur yang penting karena bisnis pada perbankan menyangkut pada adanya kepercayaan. Oleh karena hal tersebut bank harus bisa menunjukan kredibilitasnya salah satunya yaitu melalui peningkatan profitabilitas.

Kasmir, (2015) mendefinisikan "Profitabilitas adalah rasio yang digunakan untuk menilai kemampuan perusahaan didalam mencari keuntungan yang dipakai untuk mengukur kinerja manajemen dalam menghasilkan laba atau keuntungan dari operasi usaha suatu bank". Semakin tinggi dan meningkat profitabilitas maka bank tersebut semakin baik dan semakin terjamin. Pada penelitian ini, rasio profitabilitas yang digunakan yaitu Return On Asset (ROA).

Hariyani, (2010) mendefinisikan "ROA merupakan alat ukur untuk mengukur dan menilai bagaimana manajemen bank dalam kemampuannya memperoleh keuntungan yang diperoleh dari rata-rata total asset bank yang bersangkutan”. Dengan semakin besar nilai Rasio Return On Asset (ROA) maka akan semakin banyak pula besarnya keuntungan yang nanti akan diperoleh dan akan semakin kecil kemungkinan suatu bank yang akan bermasalah.

Data publikasi tahunan bank umum syariah berikut ini menunjukan perkembangan ROA perbankan syariah dapat dilihat sebagai berikut:

Tabel 1. Return On Asset Bank Umum Syariah Periode 2016-2018

\section{Return On Asset}

\begin{tabular}{clll}
\hline Tahun & BRI Syariah & BNI Syariah & Muamalat \\
$\mathbf{2 0 1 6}$ & $0,95 \%$ & $1,43 \%$ & $0,22 \%$ \\
$\mathbf{2 0 1 7}$ & $0,51 \%$ & $1,31 \%$ & $0,11 \%$ \\
$\mathbf{2 0 1 8}$ & $0,43 \%$ & $1,42 \%$ & $0,08 \%$ \\
\hline
\end{tabular}

Sumber: Annual Report diolah tahun 2020

Data yang disajikan diatas menggambarkan ROA dari 3 Bank Umum Syariah. Data tersebut menunjukan dari tahun 2016 ke 2018 mengalami penurunan dari tahun ketahunnya. Berdasarkan fenomena tersebut ini diindikasikan karena sumber daya yang dimiliki (asset) bank tidak dimaksimalkan dengan baik.

Berdasarkan Annual Report BRI Syariah, (n.d.) BRI Syariah mengalami penurunan pada rasio Return On Asset itu disebabkan oleh beberapa faktor. Penyaluran pembiayaan nerupakan salah satu dari sebagian besar bank mendapatkan kontribusi penghasilan. Mayoritas portofolio pembiayaan ada pada pembiayaan murabahah dan menurunnya pembiayaan bagi hasil. 
Kita ketahui dalam meningkatkan profitabilitas khususnya rasio Return On Asset dilakukan upaya untuk memaksimalkan laba yang diperoleh, yaitu salah satunya dipengaruhi oleh pembiayaan. Pembiayaan ini adalah salah satu produk usaha bank syariah yang menghasilkan keuntungan.

Dibawah ini data perkembangan pembiayaan BRI Syariah Periode 2016-2018 berdasarkan publikasi tahunan:

Tabel 2. Pembiayaan Bank Umum Syariah Periode 2016-2018 (Dalam Miliaran Rupiah)

\begin{tabular}{llll}
\hline Tahun & Murabahah & Mudharabah & Musyarakah \\
\hline $\mathbf{2 0 1 6}$ & 10500 & 1271 & 5185 \\
$\mathbf{2 0 1 7}$ & 10457 & 840 & 5447 \\
$\mathbf{2 0 1 8}$ & 11370 & 475 & 7406 \\
\hline
\end{tabular}

Sumber: (Annual Report BRI Syariah, n.d.)

Data publikasi tahunan BRI Syariah dilihat dari ketiga jenis pembiayaan, Terhitung dari setengah profitabilitas mayoritas terdiri dari pembiayaan murabahah. Risiko pada pembiayaan murabahah lebih sedikit sehingga banyak diminati oleh nasabah maupun pihak bank. Dari pihak bank, pembiayaan murabahah memiliki jaminan lebih tinggi karena bank selaku penjual berhak meminta kelebihan atas penjualan dan pinjaman kepada nasabah.

Berbeda dengan pembiayaan murabahah, pembiayaan bagi hasil mudharabah dan musyarakah dinilai dapat menggerakan sektor riil dan dapat menggerakan roda perekonomian yang merupakan jenis penyaluran pembiayaan yang adil dan memiliki pola yang disebut kemitraan diantara bank dan nasabah, namun meskipun demikian pembiayaan bagi hasil memiliki risiko yang lebih tinggi. Yaitu apabila proyek atau usaha yang dibiayai mengalami kegagalan dan mengalami kerugian maka bank akan menannggung kerugian tersebut terutama dalam pembiayaan mudharabah karena pihak bank harus menanggung seluruh kerugian.

Pembiayaan murabahah dan pembiayaan bagi hasil mudharabah dan musyarakah akan membawa hasil yang menguntungkan bagi pihak bank umum syariah jika dalam jumlah yang sangat besar. Maka semakin besar pendapatan, akan semakin besar pula bank untuk melakukan pembayaran kewajiban kepada pihak lain. Dengan jumlah besar pembiayaan Murabahah, Mudharabah dan Musyarakah maka tentu akan mendapatkan hasil yang menguntungkan terutama pihak bank dimana semakin besar pembiayaan yang akan tersalurkan maka tentu akan semakin besar pula tingkat profitabilitas bank.

Penelitian terdahulu yang telah dilakukan, penelitian oleh Rivalah Anjani dan Maulidiyah Indira Hasmarani yang berjudul "Pengaruh Pembiayaan Mudharabah Pembiayaan Musyarakah dan Pembiayaan Murabahah Terhadap Tingkat Profitabilitas BPRS di Indonesia Periode 2012-2015”. Penulis melakukan penelitian pada BPRS dengan hasil yang menunjukan bahwa Pembiayaan mudharabah berpengaruh negatif dan signifikan terhadap tingkat profitabilitas BPRS yang diukur dengan ROE. Juga menunjukan bahwa Pembiayaan musyarakah berpengaruh positif dan signifikan terhadap tingkat profitabilitas BPRS di Indonesia. Dari hasil pengujian disimpulkan bahwa Pembiayaan mudharabah, pembiayaan musyarakah dan pembiayaan Murabahah berpengaruh positif dan signifikan terhadap tingkat profitabilitas BPRS di Indonesia. (Anjani \& Hasmarani, 2016) 
Penelitian yang dilakukan oleh Fitriyatus Sa'adah dan Jeni Susyanti yang berjudul "Pengaruh Pembiayaan Mudharabah, Musyarakah, dan Murabahah Terhadap Tingkat Profitabilitas". Penulis melakukan penelitian pada Bank Umum Syariah di Indonesia tahun 2011-2017. Hasil penelitian menunjukan pembiayaan berakad Mudharabah tidak berpengaruh signifikan terhadap profitabilitas. Sedangkan pembiayaan berakad Musyarakah berpengaruh secara signifikan terhadap profitabilitas Bank Umum Syariah di Indonesia. (Sa'adah et al., 2018)

Berdasarkan latar belakang yang telah diuraikan tersebut, maka akan dilakukan penelitian dengan judul "Pengaruh Pembiayaan Murabahah, Pembiayaan Mudharabah dan Pembiayaan Musyarakah Terhadap Tingkat Profitabilitas".

\section{KAJIAN LITERATUR Perbankan Syariah}

Bank syariah adalah bank yang menjalankan kegiatan usaha berlandaskan prinsip syariah islam. Undang-undang No 21 tahun 2008 tentang perbankan syariah menyatakan "perbankan syariah adalah segala sesuatu yang menyangkut tentang bank syariah dan unit syariah, menyangkut kelembagaan, kegiatan usaha, serta cara dan proses dalam melaksanakan usahanya". konsep dasar bank syariah didasarkan pada al-Quran dan assunah. Semua produk dan jasa yang ditawarkan dalam bank syariah tidak boleh bertentangan dengan isi al-Quran dan as-sunah.

\section{Pembiayaan}

(Ismail, 2011) mendefinisikan "pembiayaan merupakan aktivitas bank syariah dalam menyalurkan dana kepada pihak lain selain bank berdasarkan prinsip syariah". Pembiayaan merupakan pendukung investasi yang telah direncanakan dari pendanaan yang diberikan oleh suatu pihak. Pendanaan tersebut diajukan sesuai dengan kesepakatan diantara lembaga keuangan dengan pihak peminjam dan setelah jatuh tempo pengembalian utang tersebut dengan imbalan dalam bentuk bagi hasil.

Return dari atas pembiayaan pada bank syariah berbeda dengan bank konvensional, yang mana pada bank konvensional dalam bentuk bunga akan tetapi pada bank syariah dalam imbalan bagi hasil sesuai akad-akad yang disediakan di masingmasing bank syariah.

\section{Pembiayaan Murabahah}

Wasilah, (2015) mendefinisikan "murabahah adalah transaksi penjualan barang dengan menyatakan harga perolehan dan keuantungan yang disepakati diantara penjual dan pembeli". Berbeda dengan penjualan pada umumnya, dalam akad murabahah penjual dengan jelas memberi tahu kepada pembeli berapa harga pokok barang yang sebenarnya begitu pula berapa keuantungan yang didapat dari penjualan kepada pembeli hingga diperolehnya kesepakatan.

Landasan syariah pembiayaan murabahah dalam anjuran melaksanakan pembiayaan usaha tampak dalam ayat al-Qur'an, yaitu QS Al-Baqarah (2): 275 dan 282: $2: 275)$

Artinya: "Allah telah menghalalkan jual-beli dan mengharamkan riba". (QS

"Hai orang-orang yang beriman. Jika kamu melakukan transaksi utang piutang untuk jangka waktu yang ditentukan, tuliskanlah ...." (QS 2:282) 
Adapun dari sunah adalah sebagai berikut, yaitu hadits Abu Sa'id Al-Khudri bahwa Rasulullah SAW bersabda: "sesungguhnya jual beli itu harus dilakukan suka sama suka." (HR Al-Baihaqi, Ibnu Majah, dan Shahih menurut ibnu Hibban)

\section{Pembiayaan Mudharabah}

Mudharabah disebut sebagai akad kerjasama usaha diantara dua pihak yaitu yang terjadi diantara pemilik dana yang disebut shahibul maal dengan pihak pengelola dana yang disebut mudharib. Menurut Wasilah, (2015) "akad mudharabah merupakan suatu transaksi investasi yang berdasarkan kepercayaan yaitu kepercayaan dari pemilik dana dan pengelola dana".

Ascarya, (2013) mendefinisikan "Pada suatu kontrak dengan akad mudharabah pemilik modal bisa bekerjasama dengan lebih dari satu pengelola yang dapat disebut sebagai mitra usaha terhadap pengelola yang lainnya". Adapun nisbah dari bagi hasil pemilik modal dan pengelola dibagi sesusai kesepakatan ketika diawal akad yang mana besarnya tergantung kesepakatan yang telah ditetapkan. Ketika terjadi kerugian, seluruh kerugian tersebut akan ditanggung oleh pemilik modal namun, selama kerugian tersebut bukan berasal dari adanya kelalaian pengelola dana (mudharib).

Landasan syariah Mudharabah menurut Ismail, (2011) anjuran melaksanakan pembiayaan usaha tampak dalam ayat al-Qur'an, yaitu: Shaad (38): 24

Artinya: "Dan sesungguhnya kebanyakan dari orang-orang yang berserikat itu sebagian mereka berbuat dzalim kepada sebagian yang lain kecuali orang yang beriman dan mengerjakan amal shaleh"

Sedangkan dari sunah adalah hadits Abu Hurairah, Rasulullah SAW bersabda: "sesungguh-nya Allah Azza Wa Jalla berfirman, Aku pihak ketiga dari dua orang yang berserikat selama salah satunya tidak mengkhianati lainnya." (HR. Abu Dawud dalam kitab Al-Buyu' dan Al-Hakim)

\section{Pembiayaan Musyarakah}

Wasilah, (2015) mendefinisikan "musyarakah merupakan akad kerjasama diantara pemilik modal yang mencampurkan modal mereka dengan tujuan mencari keuntungan". Akad Musyarakah adalah akad kerjasama usaha yang terjalin diantara dua pihak atau lebih yang mana masing-masing pihak memberikan kontribusi dana berdasarkan kesepakatan, apabila usaha tersebut menghasilkan keuntungan maka keuntungan tersebut akan dibagi sesuai kesepakatan pada awal akad akan tetapi jika mengalami kerugian maka kerugian tersebut dibagi sesuai dengan porsi kontribusi dana masing-masing mitra.

Landasan syariah pembiayaan musyarakah menurut Ismail, (2011) landasan syariah dari pembiayaan musyarakah yaitu sebagai berikut:

Dari Al-Qur'an bahwa landasan syariah pembiayaan mudharabah dalam anjuran melaksanakan pembiayaan usaha tampak dalam ayat al-qur'an, yaitu: QS. Shaad (38): 23-24

Artinya: "Sesungguhnya saudaraku ini mempunyai sembilan puluh sembilan ekor kambing betina dan aku mempunyai seekor saja. Maka Dia berkata: "Serahkanlah kambingmu itu kepadaku dan Dia mengalahkan aku dalam perdebatan". Daud berkata: "Sesungguhnya Dia telah berbuat zalim kepadamu dengan meminta kambingmu itu untuk 
ditambahkan kepada kambingnya. dan Sesungguhnya kebanyakan dari orang-orang yang berserikat itu sebahagian mereka berbuat zalim kepada sebahagian yang lain, kecuali orang-orang yang beriman dan mengerjakan amal yang saleh; dan Amat sedikitlah mereka ini". dan Daud mengetahui bahwa Kami mengujinya; Maka ia meminta ampun kepada Tuhannya lalu menyungkur sujud dan bertaubat”. (QS. Shaad 23-24)

Sedangkan dari sunah adalah hadits dari Abu Hurairah, Rasulullah SAW bersabda: "Aku adalah pihak keyiga dari dua orang yang berserikat selama salah satu pihak tidak mengkhianati yang lain. Jika salah satu pihak telah berkhianat maka Aku keluar dari mereka." (HR. Abu Daud yang disahihkan oleh Al-Hakim dari Abu Hurairah).

\section{Profitabilitas}

Kasmir, (2015) mendefinisikan "Rasio profitabilitas merupakan rasio untuk menilai kemampuan perusahaan dalam mencari keuntungan menunjukan efektivitas manajemen suatu perusahaan".

Hasil dari pengukuran rasio ini dapat dijadikan evaluasi dalam kinerja manajemen perusahaan untuk menilai apakah telah bekerja secara efektif atau tidak. Tujuan dari pengukuran ini yaitu untuk melihat perkembangan perusahaan dalam suatu waktu apakah mengalami peningkatan atau penurunan dan juga mencari penyebabnya.

Rasio profitabilitas pada perbankan syariah ditujukan untuk tingkat efektivitas yang diraih melalui usaha operasional bank. Rasio ini merupakan rasio yang menilai kemampuan perusahaan dalam menghasilkan laba atau profit.

\section{Return On Asset (ROA)}

(Kasmir, 2015) mendefinisikan "ROA merupakan rasio yang menggambarkan kemampuan bank dalam mengelola dana yang diinvestasikan dalam keseluruhan aktiva yang menghasilkan keuntungan". Return on Assets (ROA) merupakan gambaran dari produktifitas bank didalam mengelola dana sehingga menghasilkan laba atau keuntungan. Return On Assets dapat dirumuskan:

$$
\mathrm{ROA}=\frac{\text { Laba Bersih }}{\text { Total Aset }} \times 100 \%
$$

ROA dipakai manajemen untuk mengukur kemampuan memperoleh keuntungan dalam laba sebelum pajak yang mana keuntungan ini diperoleh dari rata-rata total asset bank tersebut. Apabila semakin besar ROA maka akan semakin besar pula tingkat keuntungan bank dan semakin baik posisi bank dari segi penggunaan asset. Laba sebelum pajak itu sendiri yaitu laba bersih yang dihasilkan dari kegiatan sebelum pajak.

\section{Metode Penelitian}

\section{Objek Penelitian}

Objek penelitian dalam penelitian ini adalah laporan keuangan pada Bank Umum Syariah di Indonesia pada BRIsyariah, BNI Syariah dan Bank Muamalat Indonesia pertriwulan selama periode 2016-2019.

\section{Populasi dan Sampel}

Dalam penentuan populasi dalam penelitian ini yaitu seluruh Bank Umum Syariah di Indonesia menurut (Otoritas Jasa Keuangan, n.d.) yaitu terdaftar ada 14 Bank Umum 
Syariah. Teknik pengambilan sampel yang digunakan pada penelitian ini yaitu metode Purposive Sampling. Sehingga terpilih 3 Bank Umum Syariah yang menjadi sampel.

\section{Operasionalisasi Variabel}

Berikut operasionalisasi variabel pada penelitian ini:

Tabel 3. Operasionalisasi Variabel

\begin{tabular}{|c|c|c|c|c|c|}
\hline No & Variable & Definisi & Indikator & Ukuran & Skala \\
\hline 1 & $\begin{array}{l}\text { Pembiayaan } \\
\text { Murabahah } \\
\text { (X1) }\end{array}$ & $\begin{array}{l}\text { "pembiayaan } \\
\text { murabahah adalah akad } \\
\text { jual beli atas barang } \\
\text { tertentu, dimana } \\
\text { penjual menyebutkan } \\
\text { harga pembelian } \\
\text { barang kepada pembeli } \\
\text { kemudian menjual } \\
\text { kepada pembeli dengan } \\
\text { meyebutkan } \\
\text { keuntungan yang } \\
\text { diharapkan." (Ismail, } \\
\text { 2011) }\end{array}$ & $\begin{array}{l}\text { Menggambarka } \\
\text { n besarnya } \\
\text { tingkat } \\
\text { pembiayaan } \\
\text { murabahah yang } \\
\text { disalurkan pada } \\
\text { tiga Bank } \\
\text { Umum Syariah } \\
\text { di Indonesia }\end{array}$ & $\begin{array}{l}\text { Total } \\
\text { Pembiayaan } \\
\text { murabahah/total } \\
\text { keseluruhan } \\
\text { pembiayaan x } \\
100 \%\end{array}$ & Rasio \\
\hline 2 & $\begin{array}{l}\text { Pembiayaan } \\
\text { Mudharabah } \\
\text { (X2) }\end{array}$ & $\begin{array}{l}\text { "Pembiayaan } \\
\text { Mudharabah } \\
\text { merupakan akad } \\
\text { pembiayaan antara } \\
\text { bank syariah sebagai } \\
\text { shahibul maal dan } \\
\text { nasabah sebagai } \\
\text { mudharib untuk } \\
\text { melaksanakan kegiatan } \\
\text { usaha dimana bank } \\
\text { memberikan modal } \\
\text { 100\% dan nasabah } \\
\text { yang menjalankan } \\
\text { usahanya." (Ismail, } \\
\text { 2011) }\end{array}$ & $\begin{array}{l}\text { Menggambarka } \\
\mathrm{n} \text { besarnya } \\
\text { tingkat } \\
\text { pembiayaan } \\
\text { mudharabah } \\
\text { yang disalurkan } \\
\text { pada tiga Bank } \\
\text { Umum Syariah } \\
\text { di Indonesia }\end{array}$ & $\begin{array}{l}\text { Total } \\
\text { Pembiayaan } \\
\text { mudharabah/tota } \\
1 \text { keseluruhan } \\
\text { pembiayaan x } \\
100 \%\end{array}$ & Rasio \\
\hline 3 & $\begin{array}{l}\text { Pembiayaan } \\
\text { Musyarakah } \\
\text { (X3) }\end{array}$ & $\begin{array}{l}\text { "Pembiayaan } \\
\text { Musyarakah } \\
\text { merupakan akad } \\
\text { kerjasama usaha antara } \\
\text { dua pihak atau lebih } \\
\text { dalam menjalankan } \\
\text { usaha, dimana masing- } \\
\text { masing pihak } \\
\text { menyertakan modalnya } \\
\text { sesuai dengan } \\
\text { kesepakatan dan bagi } \\
\text { hasil usaha diberikan } \\
\text { sesuai dengan } \\
\text { kontribusi dana atau } \\
\text { kesepakatan bersama." } \\
\text { (Ismail, 2011) }\end{array}$ & $\begin{array}{l}\text { Menggambarka } \\
\mathrm{n} \text { besarnya } \\
\text { tingkat } \\
\text { pembiayaan } \\
\text { musyarakah } \\
\text { yang disalurkan } \\
\text { pada tiga Bank } \\
\text { Umum Syariah } \\
\text { di Indonesia }\end{array}$ & $\begin{array}{l}\text { Total } \\
\text { Pembiayaan } \\
\text { musyarakah/total } \\
\text { keseluruhan } \\
\text { pembiayaan x } \\
100 \%\end{array}$ & Rasio \\
\hline
\end{tabular}




\begin{tabular}{lllll}
\hline 4 Profitabilita & Profitabilitasmerupaka & Menggambarka & Laba & Rasio \\
s (Y) & n rasio untuk menilai & n besarnya & Bersih/Total & \\
& kemampuan & tingkat Return & Aset x 100\% & \\
perusahaan dalam & On Asset & & \\
mencari keuntungan & (ROA) yang & & \\
& yang memberikan & disalurkan pada & & \\
& ukuran tingkat & tiga Bank & \\
efektivitas manajemen & Umum Syariah & \\
& suatu perusahaan." & di Indonesia & \\
& (Kasmir, 2015) & & \\
& & & \\
& &
\end{tabular}

\section{Teknik Analisis Data}

Uji Normalitas

Nugroho (et al., 2019) mendefinisikan "ujinormalitas merupakan pengujian asumsi untuk mengetahui data hasil penelitian berdistribusi normal atau tidak". Apabila tidak terdistribusi normalnya residual data maka, statistik akan menjadi tidak valid. Adapun utuk mendeteksi residual data berdistribusi normal ataukah tidak ada dua cara, yaitu dengan melihat grafik normal probility plot dan uji statistic one-Sample Kolmogorov Smirnov.

Grafik normal probility plot terlihat dengan adanya titik menyebar berhimpit di sekitar garis diagonal dan serah mengiringi garis diagonal maka dinyatakan residual data terdistribusi normal, ataupun data jugamemenuhi asumsi klasik normalitas. Kemudian, dapat dilakukan dengan uji statistic One-Sample Kolmogorov-Smirnov Test.

\section{Uji Regresi Linear Berganda}

Analisis ini digunakan untuk menguji hipotesis yang digunakan dengan software SPSS. Analisis Linier Berganda dapat dirumuskan sebagai berikut (Nugroho et al., 2019)

$\mathrm{Y}=\alpha+\beta 1 \mathrm{X} 1+\beta 2 \mathrm{X} 2+\beta 3 \mathrm{X} 3+\varepsilon$

Dimana : $\mathrm{Y}=\mathrm{ROA}$

$\alpha=$ Koefisien

$\beta=$ Koefisien Regresi

$\mathrm{X} 1$ = Pembiayaan Murabahah

X2 = Pembiayaan Mudharabah

X3= Pembiayaan Musyarakah

$\varepsilon=$ Standart Error

\section{Uji Hipotesis}

Uji T

Uji t pada penelitian ini bertujuan untuk mengetahui adanya hubungan dan menguji hipotesis diantara dua variabel atau lebih. Dapat menggunakan analisis ampel lebih dari 10. Uji t dapat dilihat dengan pengujian:

$$
t_{\text {hitung }}>\mathrm{t}_{\text {tabel }} \text { maka } \mathrm{H}_{0} \text { dinyatakan ditolak dan } \mathrm{H}_{\mathrm{a}} \text { diterima }
$$


$t_{\text {hitung }}<\mathrm{t}_{\text {tabel }}$ maka $\mathrm{H}_{0}$ dinyatakan diterima dan $\mathrm{H}_{\mathrm{a}}$ ditolak.

Uji F

Uji $\mathrm{F}$ bertujuan untuk mengetahui pengaruh simultan variabel independen terhadap variabel dependen. Dengan menggunakan uji $\mathrm{F}$ peneliti dapat menguji $\mathrm{H}_{0}$ bahwa koefisien determinasi majemuk dalam populasi $=$ nol. Untuk menentukan uji $\mathrm{F}$ dapat menggunakan rumus (Nugroho et al., 2019):

$$
\mathrm{F}=\frac{R^{2} /(k-1)}{\left(1-R^{2}\right) /(n-\varepsilon)}
$$

Dapat dinyatakan bahwa signifikansi $\mathrm{F}<0,05$ maka $\mathrm{H}_{0}$ tersebut ditolak yangartinya ada pengaruh secara simultan pada variabel-variabel independen. Begitu pula sebaliknya, jika $\mathrm{F}>0,05$ berarti $\mathrm{H}_{0}$ dinyatakan diterima dan tidak adanya pengaruh antara variabel-variabel independen.

\section{HaSil dan Pembahasan \\ Gambaran Umum PT. BRI Syariah}

Berdirinya PT. Bank BRI Syariah Tbk yang mana selanjutnya diberi nama BRI Syariah ini tidak lepas dari akuisisi yang dilakukan PT. Bank Rakyat Indonesia (Persero) Tbk terhadap Bank Jasa Arta pada 19 Desember 2007. Kemudian Bank Indonesia memberikan izin usaha melalui surat no. 10/67/KEP.GBI/DPG/2008 pada 16 Oktober 2008 BRI Syariah resmi beroprasi pada 17 November 2008 dengan nama PT. Bank Bri Syariah dan semua kegiatan usahanya berlandaskan prinsip syariah islam.

\section{Visi dan Misi PT. BRI Syariah}

Visi

Menjadi Bank ritel modern terkemuka dengan ragam layanan finansial sesuai kebutuhan nasabah dengan jangkauan termudah untuk kehidupan lebih bermakna.

Misi

1) Memahami keragaman individu dan mengakomodasi beragam kebutuhan finansial nasabah.

2) Menyediakan produk dan layanan yang mengedepankan etika sesuai dengan prinsip-prinsip syariah.

3) Menyediakan akses ternyaman melalui berbagai sarana kapan pun dan dimana pun.

4) Memungkinkan setiap individu untuk meningkatkan kualitas hidup dan menghadirkan ketenteraman pikiran.

\section{Gambaran Umum PT. BNI Syariah}

PT Bank BNI Syariah yang mana saat ini disebut BNI Syariah atau Perseroan merupakan hasil proses spin off dari Unit Usaha Syariah (UUS) PT Bank Negara Indonesia (Persero) Tbk yang telah beroperasi sejak 29 April 2000 dan dilandasi dengan terbitnya UU No. 21 tahun 2008 tentang Perbankan Syariah. BNI Syariah resmi beroperasi pada 19 Juni 2010 setelah membuat surat keputusan Gubernur Bank Indonesia No. 12/41/KEP.GBI/2010 tanggal 21 Mei 2010. 
Adapun Visi BNI Syariah adalah sebagai berikut: Misi

Menjadi bank syariah pilihan masyarakat yang unggul dalam layanan dan kinerja.

1) Memberikan kontribusi positif kepada masyarakat dan peduli pada kelestarian lingkungan.

2) Memberikan solusi bagi masyarakat untuk kebutuhan jasa perbankan syariah.

\section{Gambaran Umum PT. Bank Muamalat Indonesia}

PT Bank Muamalat Indonesia Tbk ("Bank Muamalat Indonesia") memulai perjalanan bisnisnya sebagai Bank Syariah pertama di Indonesia pada 1 November 1991 atau 24 Rabi'us Tsani $1412 \mathrm{H}$. Pendirian Bank Muamalat Indonesia digagas oleh Majelis Ulama Indonesia (MUI), Ikatan Cendekiawan Muslim Indonesia (ICMI) dan pengusaha muslim yang kemudian mendapat dukungan dari Pemerintah Republik Indonesia. Sejak resmi beroperasi pada 1 Mei 1992 atau 27 Syawal 1412 H, Bank Muamalat Indonesia terus berinovasi dan mengeluarkan produkproduk keuangan syariah seperti Asuransi Syariah (Asuransi Takaful), Dana Pensiun Lembaga Keuangan Muamalat (DPLK Muamalat) dan multifinance syariah (Al-Ijarah Indonesia Finance) yang seluruhnya menjadi terobosan di Indonesia. Selain itu produk Bank yaitu Shar-e yang diluncurkan pada tahun 2004 juga merupakan tabungan instan pertama di Indonesia.

\section{Visi dan Misi PT. Bank Muamalat Indonesia}

Visi

Menjadi bank syariah terbaik dan termasuk dalam 10 besar bank di Indonesia dengan eksistensi yang diakui di tingkat regional.

Misi

Membangun lembaga keuangan syariah yang unggul dan berkesinambungan dengan penekanan pada semangat kewirausahaan berdasarkan prinsip kehati-hatian, keunggulan sumber daya manusia yang islami dan professional serta orientasi investasi yang inovatif, untuk memaksimalkan nilai kepada seluruh pemangku kepentin

Perhitungan Pembiayaan Murabahah, Mudharabah, dan Musyarakah dan Return On Asset

Tabel 4. Pembiayaan Murabahah, Pembiayaan Mudharabah, Pembiayaan Musyarakah dan Return On Asset (ROA)

\begin{tabular}{ccccccc}
\hline $\begin{array}{c}\text { Nama } \\
\text { Bank }\end{array}$ & Tahun & Triwulan & $\begin{array}{c}\text { Pembiayaan } \\
\text { Murabahah }\end{array}$ & $\begin{array}{c}\text { Pembiayaan } \\
\text { Mudharabah }\end{array}$ & $\begin{array}{c}\text { Pembiayaan } \\
\text { Musyarakah }\end{array}$ & $\begin{array}{c}\text { Profitabilitas } \\
\text { (ROA) }\end{array}$ \\
\hline $\begin{array}{c}\text { BRI } \\
\text { syariah }\end{array}$ & 2016 & I & 14.342 .672 & 1.182 .976 & 5.125 .290 & $0,99 \%$ \\
& & II & 15.260 .674 & 1.356 .304 & 5.266 .046 & $1,03 \%$ \\
& & III & 15.079 .392 & 1.348 .919 & 5.230 .683 & $0,98 \%$ \\
& \multirow{2}{*}{2017} & IV & 15.100 .133 & 1.285 .582 & 5.379 .830 & $0,95 \%$ \\
& & I & 15.195 .847 & 1.209 .727 & 5.123 .312 & $0,65 \%$ \\
& & II & 15.344 .742 & 1.094 .125 & 5.443 .444 & $0,71 \%$ \\
& \multirow{2}{*}{2018} & III & 15.097 .519 & 968.464 & 5.698 .069 & $0,82 \%$ \\
& & IV & 15.083 .878 & 858.019 & 5.577 .220 & $0,51 \%$ \\
& II & 15.179 .333 & 742.299 & 5.915 .398 & $0,86 \%$ \\
& & & 15.663 .354 & 648.128 & 6.958 .811 & $0,92 \%$
\end{tabular}




\begin{tabular}{|c|c|c|c|c|c|c|}
\hline & & III & 16.049 .209 & 566.822 & 7.035 .696 & $0,77 \%$ \\
\hline & & IV & 16.008 .953 & 484.847 & 7.748 .129 & $0,43 \%$ \\
\hline & 2019 & I & 16.405 .457 & 405.300 & 8.350 .601 & $0,43 \%$ \\
\hline & & II & 17.232 .763 & 439.824 & 8.839 .640 & $0,32 \%$ \\
\hline & & III & 18.104 .869 & 407.037 & 9.904 .817 & $0,32 \%$ \\
\hline & & IV & 18.757 .429 & 414.096 & 11.383 .021 & $0,31 \%$ \\
\hline & 2016 & $\mathrm{I}$ & 22.033 .706 & 1.233 .878 & 2.456 .887 & $1,65 \%$ \\
\hline & & II & 23.097 .149 & 1.296 .899 & 2.732 .566 & $1,59 \%$ \\
\hline BNI & & III & 23.752 .721 & 1.293 .605 & 2.856 .345 & $1,53 \%$ \\
\hline Syariah & & IV & 24.980 .801 & 1.198 .408 & 3.012 .748 & $1,44 \%$ \\
\hline & 2017 & I & 26.066 .631 & 1.102 .866 & 3.039 .940 & $1,40 \%$ \\
\hline & & II & 26.771 .636 & 1.162 .679 & 3.640 .709 & $1,48 \%$ \\
\hline & & III & 26.906 .534 & 991.129 & 3.679 .358 & $1,44 \%$ \\
\hline & & IV & 27.265 .631 & 888.794 & 4.586.209 & $1,31 \%$ \\
\hline & 2018 & I & 27.313 .502 & 815.159 & 4.701 .713 & $1,35 \%$ \\
\hline & & II & 27.677 .458 & 1.132 .183 & 5.548 .811 & $1,42 \%$ \\
\hline & & III & 28.829 .532 & 1.034 .985 & 6.373 .592 & $1,42 \%$ \\
\hline & & IV & 29.349 .587 & 949.077 & 7.325 .664 & $1,42 \%$ \\
\hline & 2019 & I & 29.587 .615 & 916.316 & 8.620 .493 & $1,66 \%$ \\
\hline & & II & 29.967 .372 & 1.168 .048 & 9.844 .328 & $1,97 \%$ \\
\hline & & III & 30.649 .480 & 1.479 .553 & 9.487 .838 & $1,91 \%$ \\
\hline & & IV & 30.549 .867 & 1.595 .373 & 9.917 .161 & $1,82 \%$ \\
\hline & 2016 & I & 23.516 .238 & 1.081 .797 & 20.757 .977 & $0,25 \%$ \\
\hline & & II & 22.985 .638 & 901.570 & 20.888 .521 & $0,15 \%$ \\
\hline Bank & & III & 22.946 .089 & 846.564 & 21.060 .075 & $0,13 \%$ \\
\hline Muama & & IV & 23.314 .382 & 828.761 & 20.900 .783 & $0,22 \%$ \\
\hline lat & 2017 & I & 23.529 .752 & 920.679 & 20.514 .248 & $0,12 \%$ \\
\hline & & II & 25.426 .566 & 879.001 & 20.451 .848 & $0,07 \%$ \\
\hline & & III & 26.196 .465 & 853.063 & 20.104 .857 & $0,11 \%$ \\
\hline & & IV & 27.016 .195 & 737.156 & 19.857 .952 & $0,11 \%$ \\
\hline & 2018 & I & 27.546 .982 & 776.148 & 19.768 .934 & $0,15 \%$ \\
\hline & & II & 25.000 .661 & 548.634 & 17.132 .543 & $0,49 \%$ \\
\hline & & III & 23.299 .767 & 477.305 & 16.855 .409 & $0,35 \%$ \\
\hline & & IV & 21.618 .823 & 437.590 & 16.543 .871 & $0,08 \%$ \\
\hline & 2019 & I & 20.896 .971 & 485.213 & 16.095 .610 & $0,02 \%$ \\
\hline & & II & 20.017 .737 & 461.934 & 15.241 .515 & $0,02 \%$ \\
\hline & & III & 19.655 .412 & 641.583 & 14.656 .737 & $0,02 \%$ \\
\hline & & IV & 19.254 .591 & 756.514 & 14.206 .884 & $0,05 \%$ \\
\hline
\end{tabular}

Sumber: Publikasi Laporan Keuangan (PT Bank BRIsyariah Tbk, n.d.), (PT. Bank BNI Syariah, n.d.), dan (PT Bank Muamalat Tbk, n.d.).

Tabel 4 diatas merupakan data laporan keuangan yang menjadi sampel pada penelitian ini terkait Pembiayaan Murabahah, Pembiayaan Mudharabah, Pembiayaan Musyarakah dan Return On Asset pada 3 Bank Umum Syariah yang menjadi sampel untuk mempermudah dalam memahami dan melihat ada peningkatan dan penuruna dari pembiayaan murabahah, pembiayaan mudharabah, pembiayan musyarakah dan Return On Asset pada 3 Bank Umum Syariah di Indonesia periode 2016-2019. 


\section{Uji Normalitas}

\section{One-Sample Kolmogorov-Smirnov Test}

$N$

Normal Parameters ${ }^{a, b}$

Most Extreme Differences

Test Statistic

Asymp. Sig. (2-tailed)

a. Test distribution is Normal.

b. Calculated from data.

c. Lilliefors Significance Correction.

$d$. This is a lower bound of the true significance.
48

, 00000

, 00182111

, 085

,085

$-, 08$

, 085

$200^{c, d}$

Sumber: Data Sekunder yang diolah dengan SPSS 24, 2020

Berdasarkan tabel 3 diatas dapat diketahui bahwa nilai Asymp.Sig (2-tailed) untuk seluruh variabel yang diteliti baik variabel independent maupun variabel dependent memiliki nilai yang signifikan, yakni lebih besar dari 0,05 yaitu $0,2(0,2>0,05)$. Dapat disimpulkan, bahwa residual berdistribusi secara normal karena memiliki tingkat signifikan lebih dari 0,05 dengan demikian, data pada penelitian ini dianggap layak untuk dipergunakan.

Data yang telah berdistribusi normal tersebut dapat juga menggunakan grafik histogram dan grafik normal P-Plot, yaitu sebagai berikut:

Gambar 1. Gambar Grafik Histogram Distribusi Data Normal

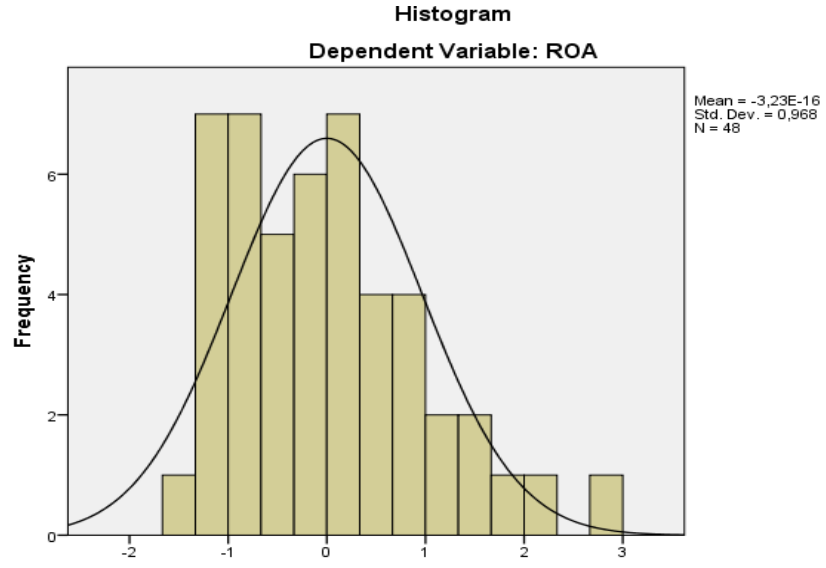

Sumber: Data Sekunder yang diolah dengan SPSS 24, 2020 
Hasil uji normalitas pada grafik diatas bahwa pada histogram tersebut telah terdistribusi normal yakni megikuti kurva membentuk lonceng yang mana kurva tersebut tidak terlihat condongkekiri ataupun condong kekanan. Oleh karena hal tersebut, maka dapat disimpulkan bahwa data tersebut telah terdistribusi normal. Hasil pengujian data dapat juga dilihat pada gambar:

Gambar 2. Gambar Grafik P-P Plot Normalitas

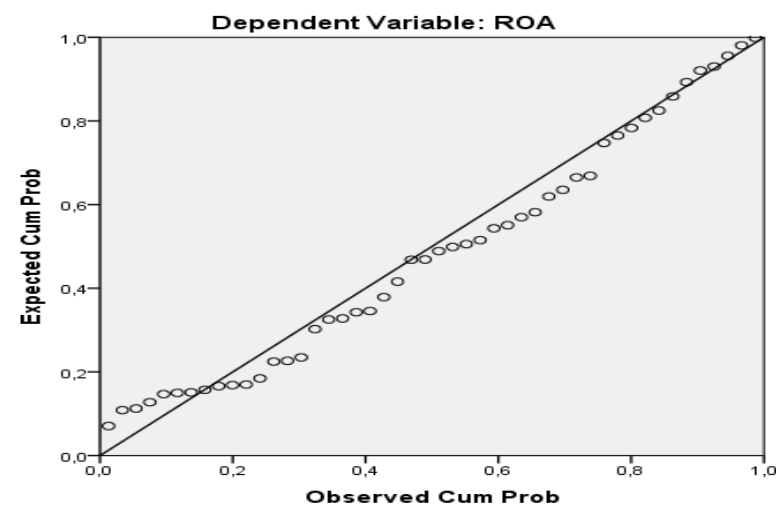

Sumber: Data Sekunder yang diolah dengan SPSS 24, 2020

Gambar diatas diketahui bahwa secara dilihat dari keseluruhan data menyebar secara diagonal dan juga mengikuti arah disekitar diagonal tersebut. Oleh karena hal tersebut, maka dapat disimpulkan dan dapat dikatakan bahwa model regresi layak untuk dipergunakan untuk pengujian karena data tersebut telah memenuhi asumsi normalitas.

\section{Analisis Regresi Linear Berganda}

Tabel 6. Analisis Regresi Linear Berganda

\section{Coefficients $^{a}$}

Model

$\begin{array}{lll}\text { Unstandardized } & \text { Standardized } \\ \text { Coefficients } & & \text { Coefficients } \\ \text { B } & \text { Std. } & \text { Beta } \\ & \text { Error } & \end{array}$

1 (Constant)

$-0,002 \quad 0,001$

$-1,434 \quad 0,159$

Pembiayaan Murabahah

$5,65 E-10$

0,000

0,477

$9,721 \quad 0,000$

Pembiayaan Mudharabah

5,21E-09

0,000

0,268

5,074

0,000

Pembiayaan Musyarakah

$-7,06 E-10$

$0,000 \quad-0,724$

$-13,912 \quad 0,000$

a. Dependent Variable: ROA

a. Dependent Variable: ROA

Sumber: Data Sekunder yang diolah dengan SPSS 24, 2020

Berdasarkan tabel 7diatas menunjukan persamaan regresi linear berganda dengan nilai:

$$
Y=-0,002+5,65 X 1+5,21 X 2+(-7,06 X 3)+\varepsilon
$$


Dari persamaan regresi datas memiliki arti sebagai berikut:

1) Konstanta $=-0,002$

Jika variabel pembiayaan murabahah $\left(\mathrm{X}_{1}\right)$, pembiayaan mudharabah $\left(\mathrm{X}_{2}\right)$ dan pembiayaan musyarakah $\left(\mathrm{X}_{3}\right)$ dianggap sama dengan nol, maka variabel Return On Asset (Y) menurun sebesar 0,002.

2) Koefisien $X_{1}=5,650$

Jika variabel pembiayaan murabahah $\left(\mathrm{X}_{1}\right)$ mengalami kenaikan sebesar satu satuan (1) maka akan mempengaruhi Return On Asset (Y) sebesar 5,650 satuan.

3) Koefisien $X_{2}=5,210$

Jika variabel pembiayaan mudharabah $\left(\mathrm{X}_{2}\right)$ mengalami kenaikan sebesar satu satuan (1), maka akan mempengaruhi Return On Asset sebesar 5,210 satuan.

4) Kefisien $X_{3}=-7,06$

Jika variabel pembiayaan musyarakah $\left(\mathrm{X}_{3}\right)$ mengalami penurunan sebesar satu satuan (1), maka akan mempengaruhi Return On Asset sebesar 7,06 satuan.

\section{Uji Hipotesis}

Uji Parsial (Uji t)

Tabel 7. Uji Parsial (Uji t) Pembiayaan Murabahah (X1)

\section{Coefficientsa}

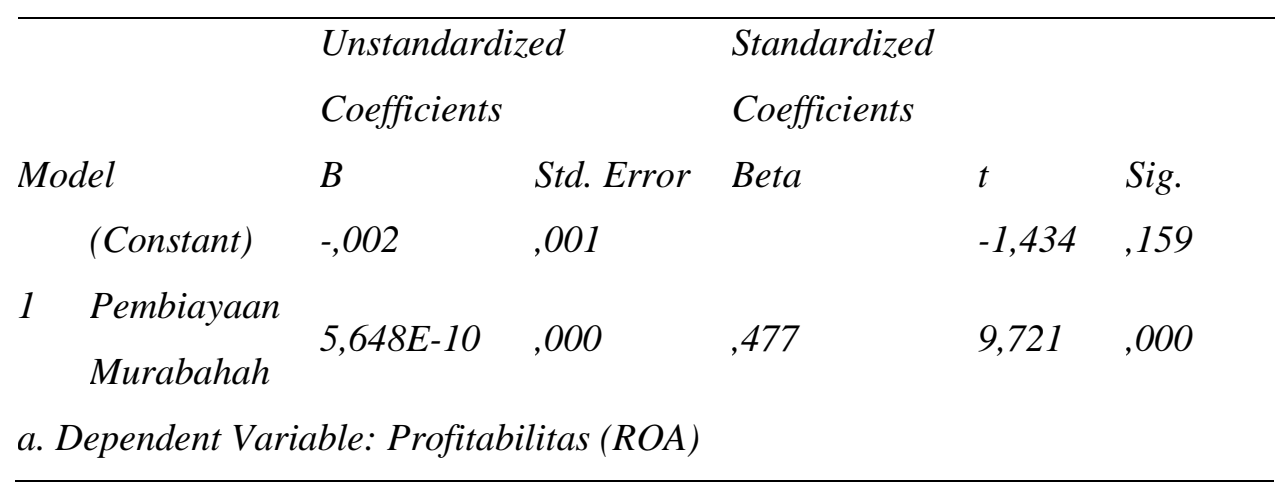

Sumber: Data Sekunder yang diolah dengan SPSS 24, 2020

Berdasarkan tabel Uji t yang telah dilakukan taraf signifikan $\alpha=0,05$ atau 5\%, df $=\mathrm{n}-\mathrm{k}-1$, maka $\mathrm{df}=48-3-1=44$, sehingga dapat diperoleh $\mathrm{t}_{\text {tabel }}$ sebesar 2,015

Berdasarkan tabel diatas, $t_{\text {hitung }}$ dari variabel Pembiayaan Murabahah $\left(\mathrm{X}_{1}\right)$ sebesar 9,721 dengan tingkat signifikan 0,000. Maka nilai $t_{\text {hitung }} 9,721>t_{\text {tabel }} 2,015$ ini artinya bahwa $\mathrm{H}_{0}$ ditolak dan $\mathrm{H}_{\mathrm{a}}$ diterima. Nilai signifikan $0,000<0,05$ ini menunjukan pengaruh yang tidak signifikan. Disimpulkan, bahwa pembiayaan murabahah berpengaruh positif terhadap Profitabilitas (ROA) pada Bank Umum Syariah Indonesia periode 2016-2019. 
Tabel 8. Uji Paesial (Uji t) Pembiayaan Mudarabah $\left(X_{2}\right)$

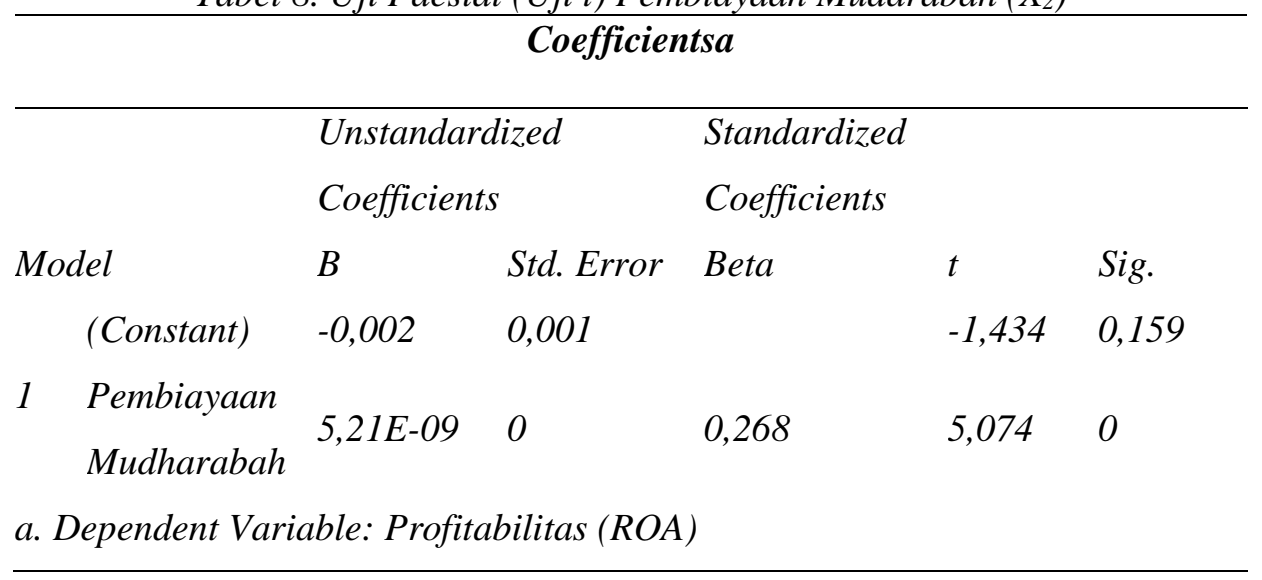

Sumber: Data Sekunder yang diolah dengan SPSS 24, 2020

Berdasarkan tabel Uji t yang telah dilakukan diatas pada variabel Pembiayaan Mudharabah dengan kriteria pengujian taraf signifikan $\alpha=0,05$ atau 5\%, $\mathrm{df}=\mathrm{n}-\mathrm{k}-1$, maka df $=48-2-1=45$, sehingga dapat diperoleh $t_{\text {tabel }}$ sebesar 2,015 Berdasarkan tabel diatas, thitung dari variabel Pembiayaan Mudharabah $\left(\mathrm{X}_{2}\right)$ sebesar -6,398 dengan tingkat signifikan 0,000. Maka nilai thitung 5,074>t tabel 2,015 ini artinya bahwa $\mathrm{H}_{0}$ ditolak dan $\mathrm{H}_{\mathrm{a}}$ diterima. Ini dapat diartikan Pembiayaan Mudharabah berpengaruh positif terhadap profitabilitas Bank Umum Syariah dan nilai signifikan $0,000<0,05$ ini menunjukan pengaruh yang tidak signifikan. Disimpulkan, bahwa Pembiayaan Mudharabah berpengaruh positif terhadap Profitabilitas (ROA) pada Bank Umum Syariah Indonesia periode 2016-2019.

Tabel 9. Uji Paesial (Uji t) Pembiayaan Musyarakah $\left(X_{3}\right)$

\section{Coefficientsa}

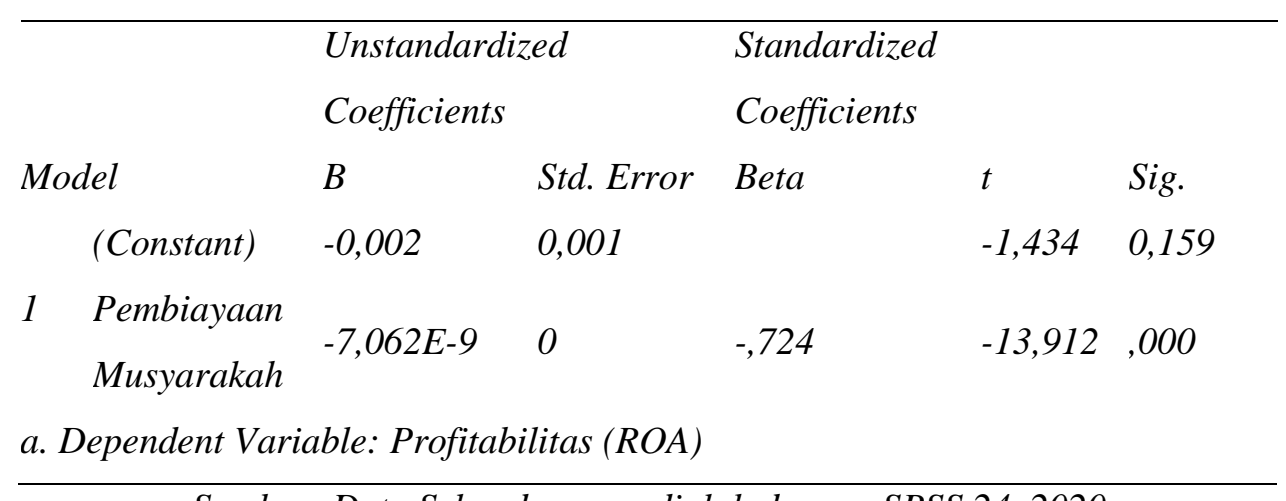

Sumber: Data Sekunder yang diolah dengan SPSS 24, 2020

Berdasarkan tabel Uji t yang telah dilakukan diatas pada variabel Pembiayaan Musyarakah dengan kriteria pengujian taraf signifikan $\alpha=0,05$ atau 5\%, df $=\mathrm{n}-\mathrm{k}-1$, maka $\mathrm{df}=48-2-1=45$, sehingga dapat diperoleh $\mathrm{t}_{\text {tabel }}$ sebesar 2,015

Berdasarkan tabel diatas, thitung dari variabel Pembiayaan Musyarakah $\left(\mathrm{X}_{3}\right)$ sebesar $-13,912$ dengan tingkat signifikan 0,000 . Maka nilai $t_{\text {hitung }}-13,912<\mathrm{t}_{\text {tabel }} 2,015$ ini artinya bahwa $\mathrm{H}_{0}$ diterima dan $\mathrm{H}_{\mathrm{a}}$ ditolak. Nilai signifikan $0,000<0,05$ ini menunjukan pengaruh yang tidak signifikan. Disimpulkan, bahwa Pembiayaan Musyarakah tidak berpengaruh positif terhadap Profitabilitas (ROA) pada Bank Umum Syariah Indonesia periode 20162019. 


\section{Uji Simultan (Uji F)}

Tabel 10. Uji Simultan (Uji F)

\begin{tabular}{|c|c|c|c|}
\hline \multicolumn{4}{|c|}{ ANOVAa } \\
\hline & & Sum of & \\
\hline \multirow[t]{2}{*}{ Model } & & Squares Df Square & Sig. \\
\hline & Regression & $3 \quad 0,001$ & $154,27,000^{b}$ \\
\hline \multirow[t]{2}{*}{1} & Residual & 440 & \\
\hline & Total & 0,002 & \\
\hline \multicolumn{4}{|c|}{ a. Dependent Variable: Profitabilitas (ROA) } \\
\hline \multicolumn{4}{|c|}{ b. Predictors: (Constant), Pembiayaan Mudharabah, } \\
\hline
\end{tabular}

Sumber: Data Sekunder yang diolah dengan SPSS 24, 2020

Berdasarkan tabel diatas, hasil Uji Simultan (Uji F) dapat diketahui terlebih dahulu bahwa kriteria dari pengujian yaitu dengan taraf signifikan $\alpha=0,05$, dengan $\mathrm{df}$ pembilang $(\mathrm{K})=3$, dan df penyebut 44 , sehingga diketahui bahwa nilai Ftabel yaitu sebesar 2,816 .

Berdasarkan hasil dari tabel diatas menunjukan bahwa nilai $F_{\text {hutung }} 154,272>F_{\text {tabel }}$ 2,816 dengan signifikan $0,000<0,05$ maka, $\mathrm{H}_{0}$ ditolak dan $\mathrm{H}_{\mathrm{a}}$ diterima yang artinya bahwa terdapat pengaruh secara simultan antara pembiayaan Murabahah, pembiayaan Mudharabah dan pembiayaan Musyarakah terhadap ptingkat profitabilitas pada Bank Umum Syariah.

\section{Koefisien Determinasi}

Hasil dari Uji Koefisien Determinasi dapat dilihat pada tabel dibawah ini:

Tabel 11. Uji Koefisien Determinasi $\left(R^{2}\right)$

\begin{tabular}{|c|c|c|c|c|}
\hline \multicolumn{5}{|c|}{ Model Summaryb } \\
\hline Model & $R$ & $\begin{array}{l}R \\
\text { Square }\end{array}$ & $\begin{array}{l}\text { Adjusted } \\
\text { Square }\end{array}$ & $\begin{array}{l}R \text { Std. Error of the } \\
\text { Estimate }\end{array}$ \\
\hline 1 &, $956^{a}$ & 0,913 & 0,907 & 0,00188 \\
\hline \multicolumn{5}{|c|}{$\begin{array}{l}\text { a. Predictors: (Constant), Pembiayaan Murabahah, Pembiayaan } \\
\text { Mudharabah, Pembiayaan Musyarakah } \\
\text { b. Dependent Variable: Profitabilitas (ROA) }\end{array}$} \\
\hline
\end{tabular}

Sumber: Data Sekunder yang diolah dengan SPSS 24, 2020

Berdasarkan tabel diatas, dapat diketahui hasil dari uji loefisien determinasi sebesar 0,913 maka hasil dari perhitungan $\mathrm{Kd}=\mathrm{R}^{2} \times 100 \%=(0,913 \times 100 \%)=91 \%$ maka disimpulkan bahwa Pembiayaan Murabahah, Pembiayaan Mudharabah dan Pembiayaan Musyarakah berpengaruh sebesar 91\% terhadap tingkat Profitabilitas pada 
Bank Umum Syariah di Indonesia periode 2016-2019, yang sisanya 9\% dipengaruhi oleh faktor-faktor lainnya yang tidak diteliti oleh penulis dalam penelitian ini.

\section{KESIMPULAN}

Dari pembahasan dan hasil diatas, maka kesimpulan dalam penelitian adalah: Pertama, Pembiayaan Murabahah $\left(\mathrm{X}_{1}\right)$ berpengaruh positif terhadap profitabilitas Bank Umum Syariah dengan hasil uji thitung sebesar 9,721 dengan tingkat signifikan 0,000. Maka nilai thitung 9,721>t tabel 2,015 ini artinya bahwa $\mathrm{H}_{0}$ ditolak dan $\mathrm{H}_{\mathrm{a}}$ diterima. Ini dapat diartikan Pembiayaan Murabahah berpengaruh terhadap profitabilitas Bank Umum Syariah dan nilai signifikan $0,000<0,05$ ini menunjukan pengaruh yang tidak signifikan. Disimpulkan, bahwa pembiayaan murabahah berpengaruh positif terhadap Profitabilitas (ROA) pada Bank Umum Syariah Indonesia periode 2016- 2019.Kedua,Pembiayaan mudharabah berpengaruh positif terhadap profitabilitas (ROA) pada Bank Umum Syariah di Indonesia pada periode 2016-2019 dengan hasil uji t sebesar 5,074 dengan tingkat signifikan $0,000<0,05$ hal ini dikarenakan pembiayaan mudharabah memiliki pengaruh yang kuat dalam Peningkatan laba yang diperoleh pada bank umum syariah yang artinya semakin meningkatnya pembiayaan mudharabah, maka akan semakin baik pula peningkatan profitabilitas Bank Umum Syariah. Ketiga, Pembiayaan musyarakah tidak berpengaruh positif terhadap profitabilitas (ROA) pada Bank Umum Syariah di Indonesia periode 2016-2019 dengan hasil uji t sebesar $-13,912$ dan tingkat signifikansi $0,00<0,05$. Pembiayaan musyarakah dapat dikatakan berpengaruh negatif terhadap profitabilitas dikarenakan pendapatan bagi hasil pada pembiayaan musyarakah ini dinilai masih belum secara optimal diperoleh dikarenakan belum mampu mengimbangi biaya-biaya yang dikeluarkan sehingga peningkatan yang terjadi pada pembiayaan ini tidak berpengaruh pada peningkatan profitabilitas. Keempat, Pembiayaan murabahah, pembiayaan mudharabah dan pembiayaan musyarakah secara simultan berpengaruh terhadap profitabilitas (ROA) pada Bank Umum Syariah periode 2016-2019 dengan hasil Uji F yaitu sebesar 154,272 dengan tingkat signifikan $0,00<0,05$. Semakin meningkatnya pembiayan murabahah dan semakin efisiennya pembiayaan bagi hasil mudharabah dan musyarakah pada Bank Umum Syariah, maka tingkat profitabilitas akan semakin tinggi pula. Sebaliknya, semakin rendahnya pembiayaan murabahah dan semakin tidak efisiennya pembiayaan bagi hasil mudharabah dan musyarakah pada Bank Umum Syariah, maka semakin rendah pula tingkat profitabilitasnya.

\section{REFERENSI}

Anjani, R., \& Hasmarani, M. I. (2016). Pengaruh Pembiayaan Mudharabah Pembiayaan Musyarakah dan Pembiayaan Murabahah Terhadap Tingkat Profitabilitas BPRS di Indonesia Periode 2012-2015. Jurnal Ekonomi \& Keuangan Islam, 2, 38-45. http://journal.uii.ac.id/index.php/jeki

Annual Report BRI Syariah. (n.d.). www.brisyariah.co.id

Ascarya. (2013). Akad dan Produk Bank Syariah. Rajawali Pers.

Hariyani, I. (2010). Restrukturisasi dan Penghapusan Kredit Macet. Kompas Gramedia.

Ismail, D. (2011). Perbankan Syariah (2nd ed.). Kencana Prenada Media Group. www.prenadamedia.com 
Kasmir. (2015). Analisis Laporan Keuangan. PT.RajaGrafindo Persada.

Nugroho, G. W., Kartini, T., Sudarma, A., Martaseli, E., Nurodin, I., Muchlis, C., Suwiryo, D. H., \& Eriswanto, E. (2019). Panduan Menulis Skripsi (I. Ismatullah (Ed.)). Cinta Buku Media.

Otoritas Jasa Keuangan. (n.d.). Statistik Perbankan Syariah. www.ojk.go.id

PT. Bank BNI Syariah. (n.d.). Annual Report BNI Syariah. www.bnisyariah.co.id

PT Bank BRIsyariah Tbk. (n.d.). Annual Report PT BRIsyariah Tbk. www.brisyariah.co.id

PT Bank Muamalat Tbk. (n.d.). Annual Report Bank Muamalat Indonesia. www.bankmuamalat.co.id

Sa'adah, F., Susyanti, J., \& Wahono, B. (2018). Pengaruh Pembiayaan Mudharabah Musyarakah dan Murabahah terhadap Profitabilitas (Studi kasus pada Bank Umum Syariah di Indonesia tahun 2011-2017). E-Jurnal Riset Manajemen. www.fe.unisma.ac.id

Wasilah, S. N. (2015). Akuntansi Syariah di Indonesia (E. S. Suharsi (Ed.)). Salemba Empat. 